\title{
MORPHOLOGICAL AND REPRODUCTIVE TRAIT-VARIABILITY OF A FOOD DECEPTIVE ORCHID, CEPHALANTHERA RUBRA ALONG DIFFERENT ALTITUDES
}

\author{
GILIÁN, L. D. ${ }^{1 *}$ - ENDRÉDI, A. ${ }^{2}-Z_{\text {ZSINKA, B. }}{ }^{3}-$ NEMÉNYI, A. ${ }^{4}-$ NAGY, J. GY. ${ }^{1}$ \\ ${ }^{1}$ Doctoral School of Biological Sciences, Institute of Botany and Ecophysiology, Szent István \\ University, H-2100 Gödöllö, Páter Károly utca 1., Hungary \\ (phone: +36-28-522-000; fax: +36-28-410-804) \\ ${ }^{2}$ Danube Research Institute, MTA Centre for Ecological Research, \\ H-1113 Budapest, Karolina út 29. \\ (phone: +36-87-448-244; fax: +36-87-448-006) \\ ${ }^{3}$ University of Veterinary Medicine, H-1078 Budapest, István u. 2. \\ (phone: +36-1-478-4100) \\ ${ }^{4}$ Institute of Horticulture, Szent István University, H-2100 Gödöllö, Páter Károly utca 1., \\ Hungary \\ (phone: +36-28-522-000; fax: +36-28-410-804) \\ *Corresponding author \\ e-mail: lilla.gilian@gmail.com
}

(Received $4^{\text {th }}$ Jan 2019; accepted $27^{\text {th }}$ Feb 2019)

\begin{abstract}
As climate change is forcing plant species to migrate northward and upward, it is important to know how species' vegetative traits and reproductive success vary along different climatic conditions. We aimed to examine the impact of elevation on the morphological and reproductive characteristics of Cephalanthera rubra in four different altitudes in Hungary: in a lowland oak forest (103 m), and in the beech forests of the Bükk-mountains $(361 \mathrm{~m}, 533 \mathrm{~m}, 657 \mathrm{~m})$. We counted the number of leaves, flowers, and fruits, and measured the height of each plant with the length and width of all leaves. Linear, negative binomial, and quasipoisson regressions were used to compare the populations. Our study has shown that the lowland and mountain populations of $C$. rubra are sharply different regarding their life history strategy and reproductive success, and altitudinal effects can be found only in the mountain populations. The number of flowers depends strongly on the vegetative production (height and leaf area) of the plants, but at the same time, the area that facilitates greater vegetative production - possibly because it also facilitates species with better competitiveness, and it is less favorable to its mimicked partners - were less beneficial in terms of fruit production.
\end{abstract}

Keywords: Orchidaceae, elevation, Hungary, height, leaf size, floral display, pollination success

\section{Introduction}

Extreme weather phenomena are becoming more and more frequent all over the world (WMO, 2011; Rahmstorf and Coumou, 2011; Coumou and Rahmstorf, 2012), which suggests that climate change is not just a future threat but is also an accelerating process in the present. The impacts of climate change can be detectable at different levels (e.g., community (Woodward et al., 1998) in species (Johnston and Schmitz, 1997), in population (Cochrane et al., 2014)) and they have already been examined on various aspects (mainly distribution (Parmesan and Yohe, 2003; Thuiller et al., 2005; Molnár V. et al., 2011) but also in survival, phenology (Fitter and Fitter, 2002; Morellato et al., 2016) or reproductive success (Ackermann, 1989; Aizen et al., 2002)) 
of many different species or communities (Parmesan and Handley, 2015; Molnár, 2015). Understanding the species' answer to this changing environment is extremely important in the case of plants, as their primary productive role is one of the essential components of almost all ecosystems on the Earth. In the context of this, the phenological or reproductive changes in the vegetation or populations may be the primary mediators for these effects on fauna and humankind (Parmesan and Hanley, 2015).

Orchidaceae is the largest family of flowering plants, incorporating almost $10 \%$ of all flowering plants, approximately 880 genera (Chase et al., 2015) and 20-30.000 species (Chase et al., 2003; Pillon and Chase, 2007). Simultaneously, it is one of the most vulnerable plant groups (Pridgeon, 1996; Scotland and Wortley, 2003; Clemente, 2009).

In general, global warming compels plants to migrate to higher latitudes and altitudes, searching for new, suitable habitats (Lenoir et al., 2008; Engler et al., 2011; Chen et al., 2011), which makes boreal and alpine vegetation and populations extremely vulnerable (Thuiller et al., 2005). Orchid populations showed a similar behaviour: in the planar region, they moved upward or poleward during the warming period (Jackson et al., 1987), while species in the mountain area with mild slopes, migrated upward along the elevation gradient (Thompson, 1990).

Availability of light and moisture is also affected by the changing climate. Orchids are known to be very sensitive to the change in the environmental factors (Fitter and Fitter, 2002; Seaton et al., 2010), and although they can tolerate slight variations in temperature and light, climate change of the last decade have forced them to migrate to more suitable places (Barman and Devadas, 2013).

During the last ca. 30 years, an increasing number of European terrestrial orchid species have experienced habitat loss (Barman and Devadas, 2013), population reduction and increased risk of extinction, thus they cannot keep pace with the climate change (Root et al., 2003; Thomas et al., 2004).

On the other hand, extreme rainfall can accelerate erosion (Selby, 1976), and an increased degree and frequency of erosion may negatively affect also the populations of orchids which live on hills (Barman and Devadas, 2013).

However, considering the life strategy components (individual survival and reproductive success) and their responses and vulnerability to biotic and abiotic environmental conditions, maintaining the highest fertilization rate is the most crucial factor for the species' survival, which highly depends on the pollinators (Tremblay et al., 2005). The flowering of orchid species and the temporal harmonization with their pollinators are the result of fine coevolution processes, leading to a high variety of flower structure and adaptation to pollination in this family, which are often in the focus of researchers (Darwin, 1984; Tremblay et al., 2005). This harmonization, as well, as directly the survival or flower/fruit production of the plants can be harmed due to climate change (Hegland et al., 2009), based on the fluctuation and change in temperature (Barman and Devadas, 2013) which is one of the main drivers of insect and plant phenology (Forest and Thompson, 2011), but we do not have enough information yet to predict the magnitude and direction of this.

To examine the potential response of morphological and phenological traits of orchids to climate change, in our study we focused on the morphological variability of a Cephalantera (Orchidaceae) species between four Hungarian populations living on different altitudes. One characteristic of this group is that various breeding and reproductive strategies are present in it (Scacchi et al., 1991). In the genus, there are 15 
food deceptive species, most of them are generalized food deceptive (Jersáková et al., 2006; Renner, 2006), but there are some species (e.g., C. rubra and C. longifolia, which also live in Hungary), which specifically imitate a special nectar producing group with Batesian mimicry. C. longifolia imitates Cistus spp. (Dafni and Ivri, 1981a,b) and $C$. rubra imitates Campanula spp. (Nilsson, 1983a). Deceptive species are strongly pollinator-limited, so that their fruit set is usually lower, than in the case of the nectar producing species (Tremblay et al., 2005). To increase the odds of the pollination, the flowering period of the generalized food deceptive species starts earlier, so that they could lure the naive pollinators (Pellissier et al., 2010a). According to Sonkoly et al. (2016), however the fruit number is low, they contain more seeds in general, as a compensation, and the gene flow is also found to be stronger within the populations than in the case of their nectar-producing relatives (Cozzolino and Widmer, 2005).

In Hungary, three species of the genus can be found: $C$. damasonium (Mill.) Druce, C. longifolia (L.) Fritsch, and C. rubra (L.) Rich (Tutin et al., 1980; Molnár, 2011). Although they frequently share the same habitat (beech forest), they show different morphological characters, as well as some differences in the flowering period (C. rubra flowers approximately 20-30 days later than the other two) (Scacchi et al., 1991). All of them are rhizomatous, perennial plants, but while $C$. longifolia is a typically outbreeding species, and $C$. damasonium is generally considered as an inbreeder (Summerhayes, 1985). C. rubra is an outbreeder which frequently reproduces vegetatively. In this latter case, a reduced ratio of plants germinated from seeds has been observed, while the number of plants originated from adventitious buds on the primary roots can be considerable (Ziegenspeck, 1936).

Considering this interesting variability in breeding systems and success, we chose Cephalanthera rubra to examine the impact of elevation (indirectly the temperature and precipitation) on the population's morphological characteristics, fecundity and reproduction strategy to predict the effects of the increasing temperature on this rare, endangered species.

C. rubra is a rhizomatous, perennial plant. The 4-10 pink flowers appear on a flexible flowering stalk, between June and at the beginning of July. Chelostoma campanularum and Ch. fuliginosum (Megachilidae) were reported as the main pollinators of the species (Nilsson, 1983b; Szlachetko and Skakuj, 1996; Newman et al., 2007).

The above-mentioned, relatively unrefined mechanism and the method of attracting pollinators by deception can explain, why most Cephalanthera species produce few ripe capsules and it gives the hypothesis that the populations are probably maintained and propagated mostly vegetatively (Delforge, 2006).

However, in the case of $C$. rubra, studies focusing on the reproduction strategy are ambivalent: on the one hand, the reproduction from seeds is considered to be dominant and vegetative propagation is sporadic (Kaźmierczakowa and Zarzycki, 2001), but in Italy a study showed that plants germinated from seeds were rare (Scacchi et al., 1991). According to Scacchi et al. (1991), C. rubra is an outbreeder, but at the same time, some results are showing that this species can frequently reproduce vegetatively.

As for the habitat, Cephalanthera rubra lives in 0-2000 m altitude, typically in scrubby grasslands, woodland margins, warmer calcareous beech forests, and oak forests. It prefers to grow in calcareous or slightly acidic soils in shaded or semi-shaded light conditions (Delforge, 1995; Vakhrameeva et al., 2008). 
The distribution area of Cephalanthera rubra extends from Northern Europe to Iran and North-Africa (Fig. 1a). The northernmost localities were found in southern Finland, where according to Tuulik (1998), the plant is infrequent and flowers very rarely. In Poland, the middle of the European distribution area of this species is known from approximately 300 localities, but only half of them have been confirmed (Kaźmierczakowa and Zarzycki, 2001). In the European Region, the populations are found throughout the temperate regions and in parts of the Mediterranean, extending from the Atlantic to the Caspian Sea. It lives in every altitude in Hungary, from planar to mountain regions. Most of the populations are found in the Transdanubian Mountains, Mecsek, North Hungarian Mountains and in the Danube-Tisza interfluvial region (Molnár, 2011) (Fig. 1b).

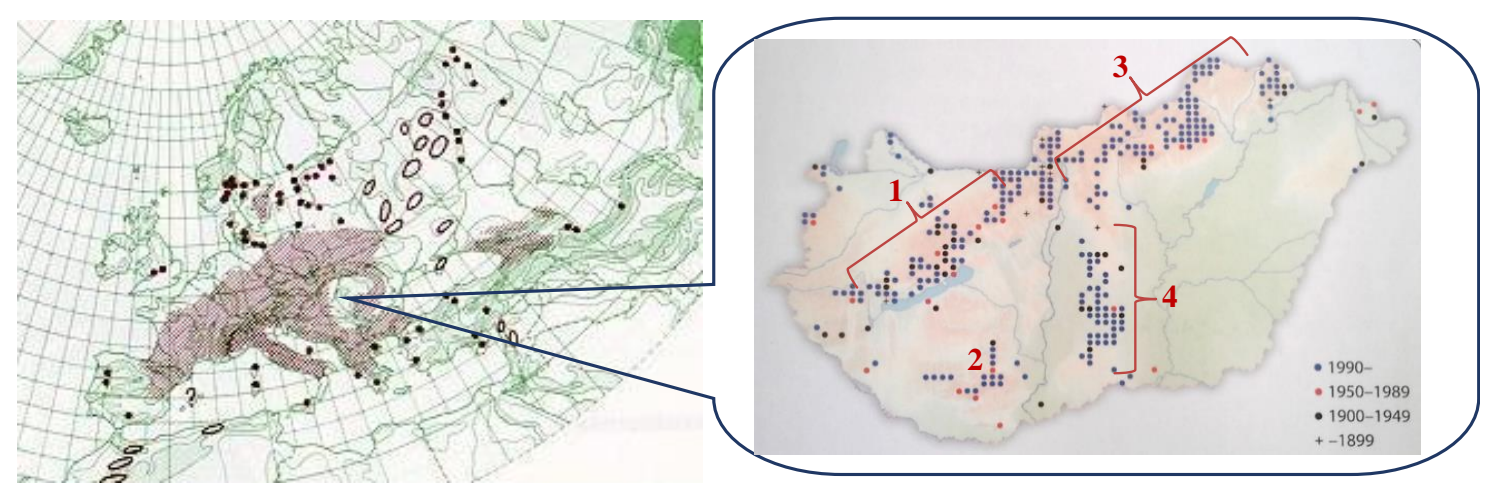

Figure 1. a Distribution of C. Rubra (http1) and b in Hungary (Molnár, 2011). 1: Transdanubian Mountains; 2: Mecsek; 3 North Hungarian Mountains; 4: Danube-Tisza interfluvial region

Although the species is widespread and often abundant, its distribution appears in small, isolated and severely fragmented populations and becomes rare in the margins of its distribution. The populations usually comprise $1-20$, very occasionally more than 100 plants (Brzosko and Wróblewska, 2003). The size of the population is suspected to be declining, and many sites have already been lost (Delforge, 1995; Lang, 2004; Newman et al., 2007; Vakhrameeva et al., 2008; Harrap and Harrap, 2009).

The IUCN degree of threat of this species on the Red List of the Vascular Flora of Hungary is Least Concern (Király, 2007). Many populations have been lost and declined due to inappropriate site management, lack of pollination, forest fires, deforestation for building and construction work purposes as well as plant collection. In addition, populations may be genetically depauperate as this species can form clonal populations (Micheneau et al., 2010). However, the species occurs in numerous European countries with less threat in some; therefore, the risk of extinction at the European level is low, and Cephalanthera rubra is assessed as Least Concern (Rankou, 2011).

Jakubska et al. (2014) have investigated the extinction of the Cephalantera species in Poland during the last 120 years, and conclude that their decline cannot be attributed to global change (climate warming or nitrogen deposition) as the shift took place in the first half of the 20th century. They suggest that the species decline should rather be explained by changes in land use, including alteration of deciduous forests into coniferous monocultures, as well as by intensification of agriculture. 
In Hungary, the declining degree of the species is 22\% (Molnár, 2011.) Some of the main reasons behind the disappearance of the species are those processes which are leading to increased shading of the forest floor (Brzosko and Wróblewska, 2003).

Regarding the predicted future changes, the Pannonian region is highly vulnerable: according to Thuiller et al. (2005), the expected species turnover in this area is about $66 \%$ which means a substantial species loss (migration to north) but also a huge species gain from the eastern Mediterranean region. Based on this, it is essential to examine the opportunities and behaviour of the Hungarian populations.

\section{Materials and methods}

\section{Study sites}

In this study, we examined four Hungarian populations in different altitudes (Fig. 2): One in the planar region (Jászfényszaru $(\mathrm{J}), 103 \mathrm{~m}$ ), and three from different elevations of the Bükk-mountains: Kis-Oltár (KO, $361 \mathrm{~m})$, Bikk-bérc (BB, $533 \mathrm{~m})$, and Pongorlyuk peak (PP, $657 \mathrm{~m})$.

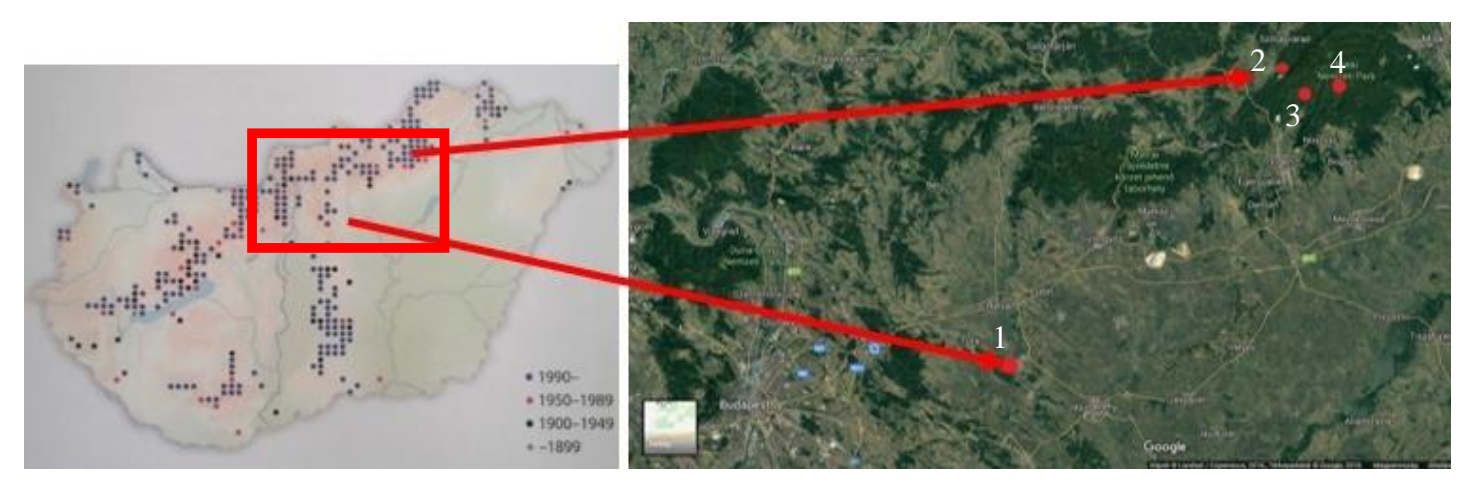

Figure 2. Habitats of the examined populations in Hungary (Molnár, 2011; GoogleEarth, 2018). 1: Jászfényszaru; 2: Kis-Oltár; 3: Bikk-bérc; 4: Pongorlyuk peak

\section{Populations on the Bükk-mountain}

The Bükk-mountain is located in the North Hungarian Mountains. We examined three populations living here, at different elevations. The soil of the study sites are brown forest soil on limestone bedrock. The annual average temperature is about $2{ }^{\circ} \mathrm{C}$ below the national average, only $7-8^{\circ} \mathrm{C}$, while on the highest part of the Bükk plateau it is even lower, only $6^{\circ} \mathrm{C}$.

Because of the continental effect, winter is cold (average temperature in January is $4{ }^{\circ} \mathrm{C}$ ), the number of snowy days are the highest in the country. Summer is warm, frequently rainy at the beginning of July and the end of August. The distribution of annual precipitation is also affected by continentality. There are two precipitation maximums, one in the early summer and one in the autumn. The annual rainfall is 600$700 \mathrm{~mm}$, and $800 \mathrm{~mm}$ on the Beech plateau. Based on data of MetNet (http2), the Walter-Lieth climate diagram (Fig. 3) represents the average climate of the study areas in the Bükk-mountain in 2018. 
It is noticeable that there were three wet periods: at the end of the winter, at the end of February and at beginning of March, when the snow melts; also in June and in September.

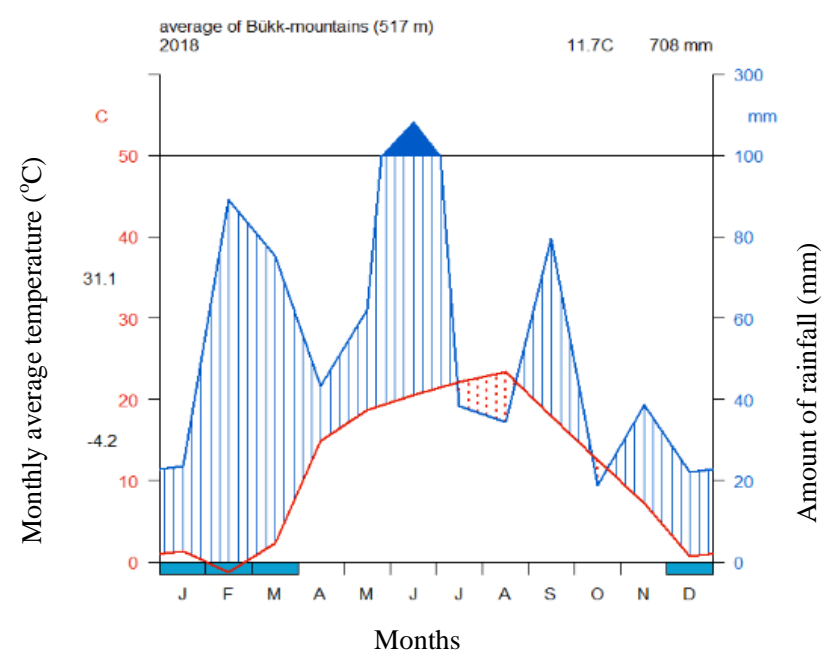

Figure 3. Walter-Lieth climate diagram of the Bükk mountain in average for 2018

Our three examined populations situated in Medio-European limestone beech forests of the Cephalantero-Fagion (Natura 2000 habitat category is 9150). All their habitats can be found in light-spotted, mostly flat, bit rocky places. The shrub layer (because of the forestry activity) and the herbaceous layer are not dense, so that the amount of light, which reaches the surface is quite a lot.

\section{The habitat of the Jászfényszaru population}

The town of Jászfényszaru is located in the Great Plain, on the sub-region called Hatvani Plane. Its climate is moderately warm and dry, the dominant soil type is pise and chernozem brown forest soil on calcareus sand at the study site.

The annual average temperature is about $11^{\circ} \mathrm{C}$. The number of sunny hours is high.

Due to the characteristics of the continental climate, distribution of precipitation shows extremities within, and also between years (MNDI, 2010). The Walter-Lieth climate diagram (Fig. 4) represents the climate of the study area in Jászfényszaru in 2018. It was made from the online data through MetNet and were drawn in RStudio program by us. As it can be seen, there were two humid periods: in February and in the middle of June.

The examined population is situated in Euro-Siberian steppic woods with Quercus robur (Natura 2000 habitat category is 91I0). It is found in the pedunculate oak forests, with high density of herbaceous- and shrub layers. The terrain is flat, as it is typical in the Great Plain.

\section{Data collection}

In our study, we examined the four populations two times in 2018. First, in the flowering period, in May-June we counted and marked all (J: 100, KO: 22, BB: 85, PP: 27 ) individuals by recording their GPS coordinates and we counted the number of 
flowers, the number of the leaves, and measured the height of each plant and the length and width of all leaves. On the second occasion, in July-August, we counted the fruits of the same plants in the cases of three populations, but in the PP population (on the highest altitude), we did not have fruit data from 10/27 plants, partly because they had not started the fruiting period yet or the fruiting stems were consumed by animals.

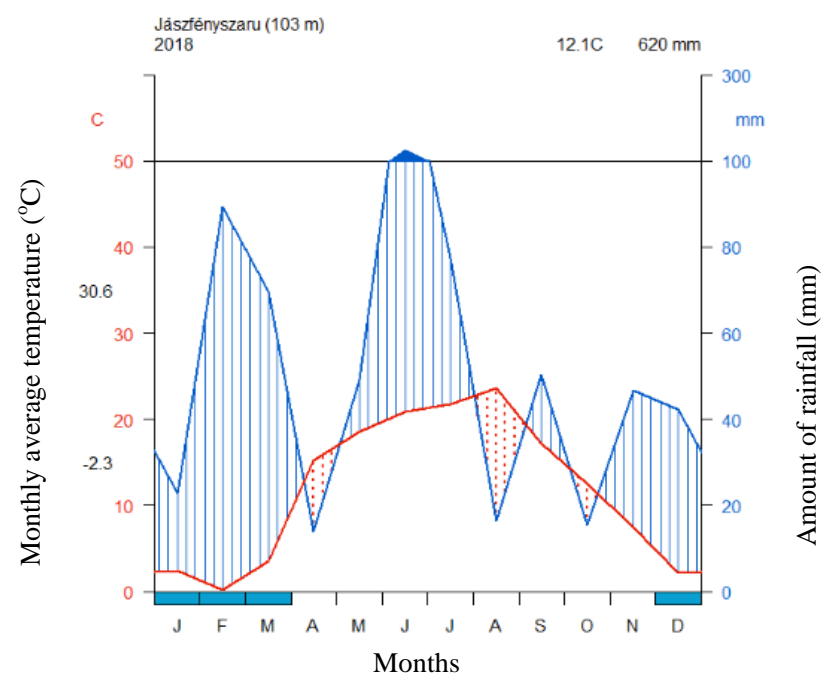

Figure 4. Walter-Lieth climate diagram of Jászfényszaru for 2018

\section{Data analysis}

Statistical analysis was made in R statistical software (R Core Team, 2017). The boxplots, scatterplots, and histograms which were used to visualize our data were made with the ggpubr package (Kassambara, 2017).

One-way analysis of variance (ANOVA, on the log-transformed height and leaf size data, $\mathrm{lm}$ function (R Core Team, 2017)), negative binomial regression (on the number of flowers and fruits, glm.nb function of the MASS package (Venables and Ripley, 2002)), and quasipoisson regression (on the number of leaves, glm function (R Core Team, 2017)) were used to compare the populations. Differences between the populations were tested with post-hoc analyses based on Tukey all-pair multiple comparisons, using the glht function of the multcomp package (Hothorn et al., 2008).

\section{Results}

\section{Growth-related traits}

Height

The average height of the plants was 29.44 centimeters, the highest individual $(71 \mathrm{~cm})$ was found in the lowest altitude $(\mathrm{J})$, while the shortest individual $(5.8 \mathrm{~cm})$ was found at the highest altitude (PP) (Fig. 5). The average heights showed the same pattern: while the mountain populations looked similar, the average height of the plants in the Jászfényszaru population was (almost two times) greater (Fig. 5b).

This difference was found to be significant ( $<<2.2 \mathrm{e}-16$; Table Al and Fig. Al in the Appendix): according to the pair-wise comparisons, at the lowest altitude (J), the 
expected average height of the plants is 2.125 (95\% CI: $[1.8 ; 2.5])$ times higher than in the BB population, and even 1.79 (95\% CI: $[1.4 ; 2.3])$ and 1.86 (95\% CI: [1.5; 2.3]) times higher than in the KO and PP populations. The three mountain populations did not differ from each other (Table Al).
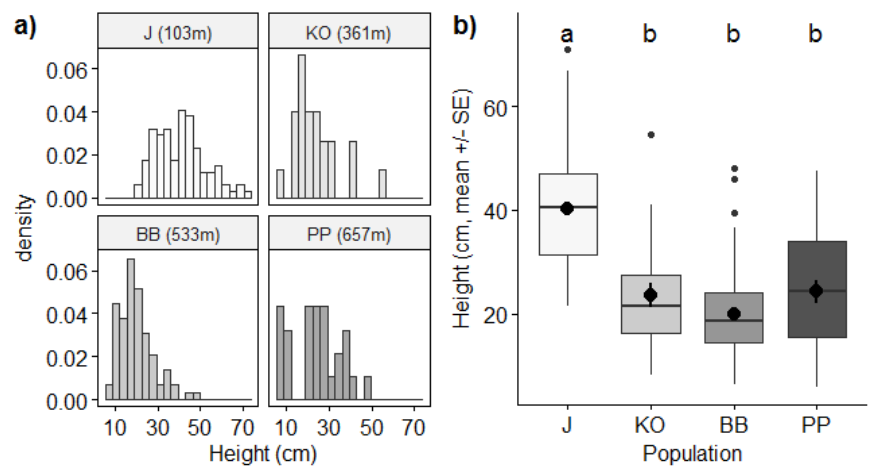

Figure 5. Histogram (a) and bloxpot (b) based on the height in the examined populations.

Significant differences are indicated by different letters

\section{Leaves}

The average number of the leaves was 4.7, the most leaves (10 pcs) were found on an individual in $\mathrm{J}$ population, while the less $(2 \mathrm{pcs})$ were found in the BB population. The number of leaves per individual showed a similar pattern (Fig. 6) as the heights of the plants (Fig. 5): individuals living at the lowest (J) altitudes had more leaves (Fig. 6b), however, in this case, only the J-BB, J-KO and PP-BB population pairs differed significantly ( $\mathrm{p}<0.001 ;$ Table A2) from each other.
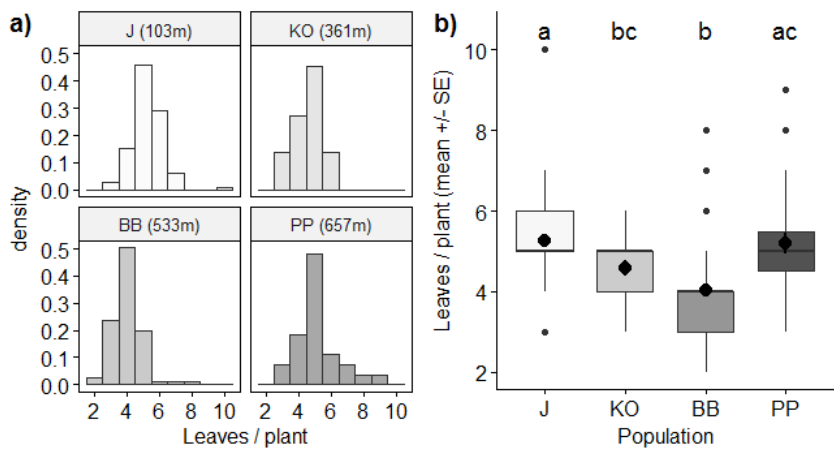

Figure 6. Histogram (a) and bloxpot (b) based on the leaves/plants in the examined populations. Significant differences are indicated by different letters

Regarding the estimated leaf size index (sum of the all leaf's lengths $\times$ leaf widths per individual), our populations looked more similar (Figs. 7 and A1). Again, only the $\mathrm{J}$ population showed a significantly higher average value than the others $(\mathrm{p}<0.001$; Table A3), which were not different from each other.

Summarizing the results regarding the growth-related traits of our populations, we can state that at a lower altitude ( $\mathrm{J}$ population) the plants showed significantly longer stems, bigger- (Fig. 5) and a higher number (Fig. 6) of leaves. The three mountain 
populations looked more similar, but because in some cases the BB population showed less production, the KO-PP population pair is considered to be the most similar regarding the growth-related traits.
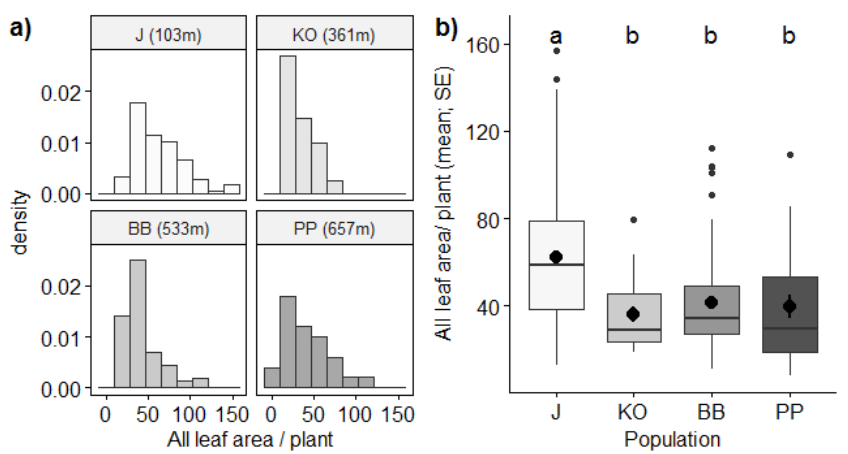

Figure 7. Histogram (a) and bloxpot (b) based on the all leaf area/plants in the examined populations. Significant differences are indicated by different letters

\section{Reproduction-related traits}

\section{Flowers}

The average number of the flowers was 4.5 , most of the flowers (20 pcs) were found on an individual in $\mathrm{J}$ population, while the fewest $(0 \mathrm{pcs})$ were found in the PP and BB populations. According to the average number of flowers per individual, we did not find huge differences between the four habitats (Figs. 8 and Al), but the pattern is similar to that regarding the number of leaves (Fig. 6). The negative binomial regression showed significantly fewer flowers at the BB populations than in the $\mathrm{J}$ and the PP populations ( $\mathrm{p}<0.001$; Table A4): The expected average flower number/individual is 1.84 times (95\% CI: $[1-38 ; 2.44])$ and 2 times $(95 \%$ CI: $[1.35 ; 3,01])$ times higher in the $\mathrm{J}$ and the $\mathrm{PP}$ populations than in the BB population.
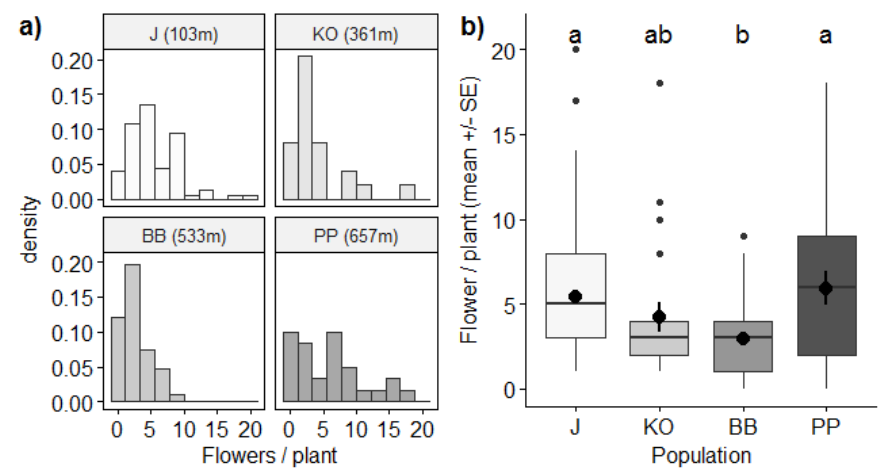

Figure 8. Histogram (a) and bloxpot (b) based on the flowers/plants in the examined populations. Significant differences are indicated by different letters

\section{Fruits}

The average number of the fruits was 1.15 , the most fruits (18 pcs) were found on an individual in KO population, while individuals with no fruits were found in all of the 
four examined populations. Although we found a little bit more flowers per individual in the J and PP populations (Fig. 8), these two populations showed the least amount of fruits (in average) because there were plenty of plants in these habitats which had no fruit at all (Fig. 9). On the other hand, in the KO population, there was a plant which had an extremely high amount (18) of fruits compared to the others. Due to this outlier, the fine differences between the populations cannot be visible on the figures (Fig. A2), thus for the better visibility, we eliminated the outlier from Figure 9 (but not from the model).
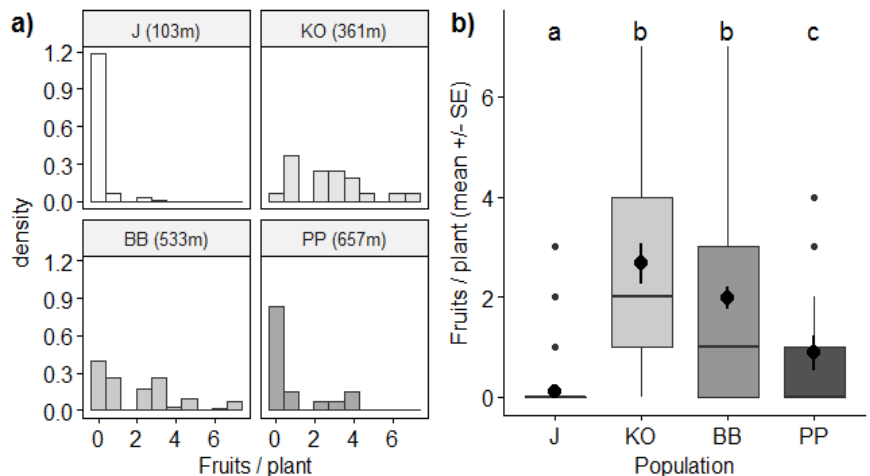

Figure 9. Histogram (a) and bloxpot (b) based on the fruits/plants in the examined populations. Significant differences are indicated by different letters

According to the model and the pair-wise comparisons, except the KO-BB population pair $(\mathrm{p}=0.177$; Table A5), all population-pairs were different considering the average number of fruits/individuals ( $\mathrm{p}<0.002$; Table A5). It is visible from these results and the figure (Fig. 9) that the population in Pongorlyuk-peak also had a significantly higher average fruit/individuals number than the Jászfényszaru population.

Based on the reproduction-related traits, the J-PP population pair seems to be the most similar, but the KO-BB population pair also behaves similarly (Fig. 10).

\section{Correlations}

From the results mentioned above, it is easy to see that the growth-related traits (height, leaf size, and leaf number) should be highly correlated with the number of flowers: the populations with higher plants (Fig. 5) and bigger leaf surface (Fig. 7) had a little bit more flowers (Fig. 8), but this does not increase the expected number of fruits (Fig. 9).

On the other hand, we checked the relationship between the growth-related traits and the number of flowers within the populations, too. In this case, both the heights (Fig. 11a) and the size of the leaves (Fig. 11b) showed a good correlation with the number of flowers, but there are some differences between the populations: the height of the plant shows a stronger relationship with the number of flowers in the cases of the $\mathrm{KO}$ and $\mathrm{BB}$ populations.

Considering the impact of the flower number on the number of fruits, Fig. 11c shows that in the cases of the mountain populations, the size of the inflorescence does not have impact on the number of the fruits. Although, in the $\mathrm{J}$ population, only individuals with 
more than 10 flowers succeeded to produce any fruits and above this threshold, the number of fruits is highly dependent from the number of flowers.

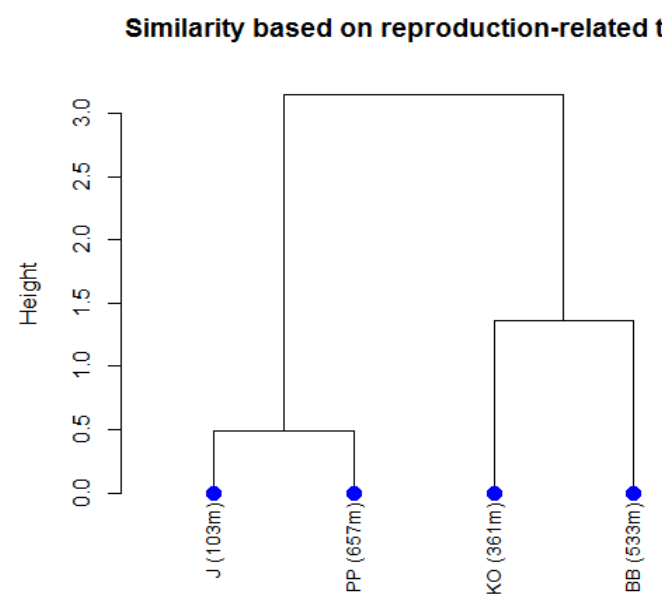

Figure10. Similarity based on reproduction-related traits
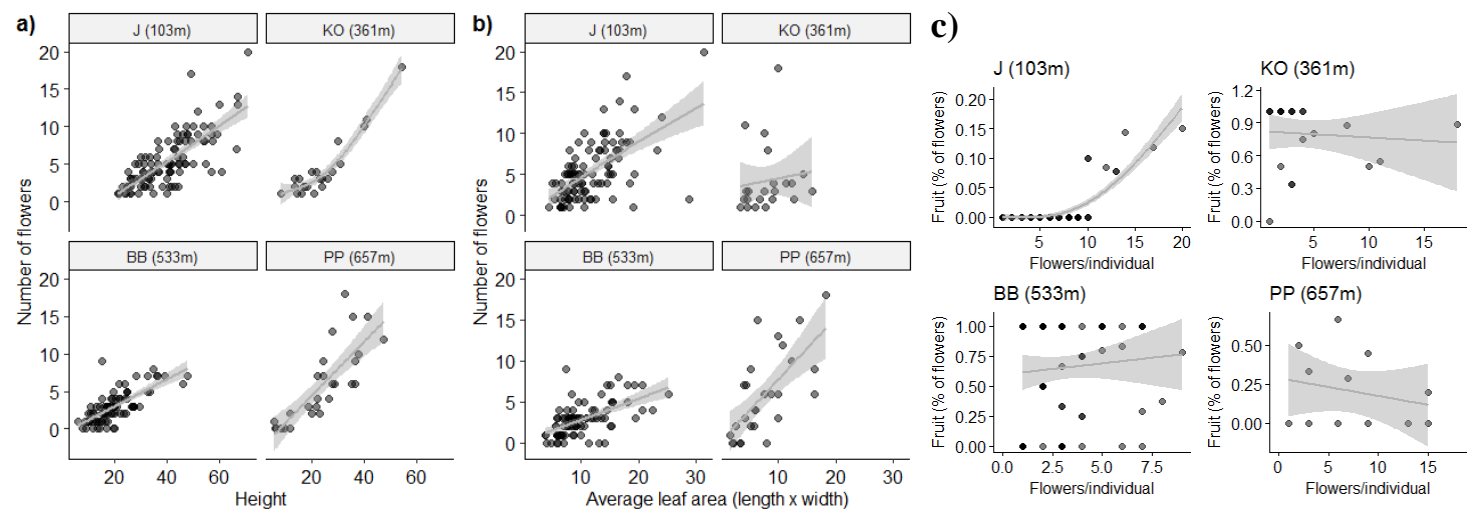

Figure 11. Relationship between the growth-related traits and the number of flowers $(a-b)$ and the impact of flower number on the fruit/flower ratio (c) within the different populations

\section{Discussion}

Latitudinal and altitudinal range shifts have been already reported for many plant species, as the borders of the vegetation zones are moving to the north and increasing in the mountain regions due to climate change (e.g., Chen et al., 2011) or other factors like land use change (e.g., Bodin et al., 2013; Jakubska-Busse et al., 2014). Recently, it is a central challenge to predict future changes in the environment, the communities and the way how different species will adapt or not to the new environmental conditions of the future.

Examining populations of the same, widespread species or a given community in different latitude or altitude can give us valuable data about the species' requirements and adaptation capability; thus future tendencies can be predicted better. E.g., recent studies have shown, that individuals of a species usually become shorter with increasing altitude due to the decrease in temperature (Bjorkman et al., 2018), vegetative reproduction can become more important on higher altitudes (Young et al., 2002) and, 
however, most montane plant species will profit from the increasing temperature (e.g., general food-deceptive orchids (Pellissier et al., 2010b)), high-elevation, cold-adapted plants are more vulnerable (Rumpf et al., 2018).

In our study, we chose Cephalanthera rubra, a widespread terrestrial orchid to see how its vegetative and reproductive traits change with altitude. The species inhabits semi-shade forests up to $2.000 \mathrm{~m}$ (Delforge, 2006), and although we do not have too much information about its altitudinal shift, Jakubska-Busse et al. (2014) found that in Poland the plant's populations moved upwards in the first half of the previous century, most probably due to land-use change. A bigger problem is that the number and size of the populations are usually small and continuously decreasing (Brzosko and Wróblewska, 2013, 2003; Scacchi et al., 1991), and the reproduction success is low (Brzosko and Wróblewska, 2013; Vakhrameeva et al., 2008), as it is in the case of every food-deceptive terrestrial orchid (Tremblay et al., 2005), which leads to low genetic diversity (Brzosko and Wróblewska, 2013; Scacchi et al., 1991), so a higher vulnerability of the populations.

In this study, we examined four populations at different altitudes. As the temperature is decreasing with increasing altitude, we expected a decrease also in height, flowering and fruit production on higher altitudes.

Although a continuous decrease in height could not be visible in our data, at the lowland (Jászfényszaru) habitat, the plants had significantly higher stems and bigger leaves than the individuals living in the Bükk-mountains, which were similar in height. On the other hand, the ratio of the flowering individuals decreased with the altitude: at the lowland habitat and the lowest mountain habitat, $100 \%$ of the examined specimens had flowers, while the flowering decreased to $90 \%$ and then to $81.5 \%$ at the highest altitudes. The decreasing temperature with increasing altitude can partially explain the flowering pattern, but light conditions can also have an impact on it. While at the lowland habitat, the canopy coverage was about $75-90 \%$, at the mountain habitats it was above $90 \%$, except a fifth of the lowest mountain habitat, where due to some treecutting, the light conditions were temporarily better than at the other two.

It is known that the species' populations and reproduction show high sensitivity to increased shading (Vakhrameeva et al., 2008; Fay and Taylor, 2015), however, the plants can get about $26 \%(\mathrm{SD}=11 \%)$ of their carbon needs from their mycorrhizal partner (Bidartondo et al., 2004), which make them moderately tolerate to shady conditions. In contrast, open habitats provide more light, - thus energy - to grow and flower, but also an increased competition which is also suspected to be disadvantageous to the plant (Fay and Taylor, 2015). It also must be noted that although the height and leaf area are considered to be a good proxy for condition and flowering capability, in the case of rhizomatous or tuberous orchids, these vegetative traits can affect more the flowering of the next year than the given year (Jersáková and Kindlman, 2002). E.g., Janečková et al. (2006) found that in the case of another nectarless orchid, Dactylorhiza majalis, the leaf area of the previous year was the best predictor of the flowering of the plants in the current year. Furthermore, although the leaf area in the given year was correlated with the height of the plant, it was affected mainly by the leaf area of the previous year (via carbohydrates stored in the tubers), while the stalk's heights could be explained more by the temperature and precipitation.

Based on these literature data, it seems that at the two lowest examined populations, the temperature and light were enough previously to all plants to produce flowers, while the more shady habitat of the highest mountain populations probably could not provide 
enough energy to make all plants flower. However, it must be noted that these decreased flowerings are still extremely high compared to the literature data which implies that the plants of these populations were in good condition in this year.

Considering the number of flowers, although there was a similar - but not significant - decreasing pattern at the three lowest habitats with the altitude, the population of the highest altitude showed more flower per individual than the expected. The ratio of fruiting individuals also showed a decrease with the altitude in the case of the mountain habitats, but was much less at the lowland habitat, and the fruit number showed a reverse pattern compared to the flower number: the lowest and highest populations which had the most flowers on average - had the least fruits per individual in general.

Deceptive orchids are strongly pollinator- and pollen-limited and their reproductive success is generally low (Tremblay et al., 2005). C. rubra is a mimicking fooddeceptive orchid which mimics the flowers of the Campanula spp. (Nilsson, 1983b; Szlachetko and Skakuj, 1996; Newman et al., 2007), and although the species is completely self-compatible, spontaneous autogamy has not been observed yet (Tałałaj et al., 2017), thus reproductive success highly depends on the presence and abundance of its pollinator and mimicked species too. The observed pollinators (Chelostoma fuliginosum (Claessens et al., 2015; Newman et al., 2007), Ch. campanularum (Nilsson, 1983b, but see Newman et al., 2007), and Miarus campanulae (Claessens et al., 2015)) are highly related to Campanula spp. Furthermore, Chelostoma species also need standing dead trunks as a nesting place.

The habitat of our lowland population has a more open canopy, which could lead to a higher irradiance but also a higher herb competition which can decrease the visibility, thus the probability of the pollination. In a habitat like this, being taller and having more flowers can be a good strategy, especially because the abundance of the mimicking species is low at the neighborhood; thus pollinator abundance should also be low. Competition for the small number of pollinators can explain, why only the striking, high, and multi-flowered individuals showed remarkable pollination success (Kindlmann and Jersáková, 2006; Suetsugu et al., 2015) and it can lead to a more frequent vegetative reproduction as well. A higher frequency of vegetative reproduction may also be suggested by the fact, that this population contained much more individuals than the other examined populations.

The mountain populations had a higher abundance of Campanula persicifolia and Campanula trachelium nearby. The Cephalanthera rubra specimens showed shorter stems than in the lowland population, and also a decrease in flowering and fruiting individuals with the altitude. The reproduction success of the two lowest mountain populations was extremely high (83-85\% of the flowers turned into fruits), while the Pongorlyuk-peak population, on the highest altitude, had a little bit more flowers but significantly fewer fruits (about $40 \%$ of the flowers turned into fruits). These results suggest that these areas are more suitable for the species, except at the highest altitude, where possibly the temperature or the irradiance is not enough to mature the fruits. On the other hand, it is worth mentioning, that the low number of fruits here does not necessarily mean low pollination success. It is also possible that the low number of fruits/individuals is attributable to the stronger herbivory pressure or some infections, as it is suggested by the fact that we have found several damaged shoots in the area. 


\section{Conclusions}

Our study has shown that the lowland and mountain population of $C$. rubra are sharply different regarding their life history strategy and reproductive success, and altitudinal effects can be found only in the mountain populations.

The number of flowers of $C$. rubra depends strongly on the vegetative production (height and leaf area) of the plants, but at the same time the area that facilitated greater vegetative reproduction - possibly because they also facilitate species with better competitiveness and less favorable to its mimicked partners - were less beneficial in terms of fruit production.

To predict the expected population dynamics, trait distributions and vulnerability of the species it is important to continue the monitoring of the examined populations and combine the results with genetic examinations.

Acknowledgements. This research was supported by the ÚNKP-18. New National Excellence Program of the Ministry of Human Capacities, Hungary. Thank you so much for this opportunity. The publication was supported by the EFOP-3.6.3-VEKOP-16-2017-00008 project. The project is co-financed by the European Union and the European Social Fund. Many thanks in the field work to Nikolett Csukás, Bernadett Hetesi, Tímea Keszthelyi, Luca Hergott, Adrián Molnár and Gábor Kadosa. Thanks for help in statistics to Zsolt Lang.

\section{REFERENCES}

[1] Ackermann, J. D. (1989): Limitations of sexual reproduction in Encyclia krugii (Orchidaceae). - Systematic Botany 14: 101-09.

[2] Aizen, M. A., Ashworth, L., Galetto, L. (2002): Reproductive success in fragmented habitats: do compatibility systems and pollination specialization matter? - Journal of Vegetation Science 13: 885-92.

[3] Barman, D., Devadas, R. (2013): Climate change on orchid population and conservation strategies: a review. - Journal of Crop and Weed 9: 1-12.

[4] Bidartondo, M. I., Burghardt, B., Gebauer, G., Bruns, T. D., Read, D. J. (2004): Changing partners in the dark: isotopic and molecular evidence of ectomycorrhizal liaisons between forest orchids and trees. - Proc. R. Soc. London. Ser. B Biol. Sci. 271: 1799-1806. DOI: 10.1098/rspb.2004.2807.

[5] Bjorkman, A. D., Myers-Smith, I. H., Elmendorf, S. C., Normand, S., Nadja, R., Beck, P. S. A., ..., Weiher, E. (2018): Plant functional trait change across a warming tundra biome. - Nature 562: 57-62.

[6] Bodin, J., Badeau, V., Bruno, E., Cluzeau, C., Moisselin, J. M., Walther, G. R., Dupouey, J. L. (2013): Shifts of forest species along an elevational gradient in Southeast France: climate change or stand maturation? - J. Veg. Sci. 24: 269-283. DOI: 10.1111/j.16541103.2012.01456.x.

[7] Brzosko, E., Wróblewska, A. (2003): Genetic variation and clonal diversity in island Cephalanthera rubra populations from the Biebrza National Park, Poland. - Botanical Journal of the Linnean Society 143: 99-108. DOI: 10.1046/j.1095-8339.2003.00201.x.

[8] Brzosko, E., Wróblewska, A. (2013): Genetic diversity of nectar-rewarding Platanthera chlorantha and nectarless Cephalanthera rubra. - Botanical Journal of the Linnean Society 171(4): 751-763.

[9] Chase, M. W., Cameron, K. M., Barrett, L. R., Freudenstein, J. V. (2003): DNA Data and Orchidaceae Systematics: A New Phylogenetic Classification. - In: Dixon, K. W., Kell, S. P., Barrett, R. L., P. J. Cribb (eds.) Orchid Conservation. Natural History Publications, Kota Kinabalu, Sabah, Malaysia, pp. 69-89. 
[10] Chase, M. W., Cameron, K. M., Freudenstein, J. V., Salazar, G., Van den Berg, C., Schuiteman, A. (2015): An updated classification of Orchidaceae. - Botanical Journal of the Linnean Society 177: 151-74.

[11] Chen, I. C., Hill, J. K., Ohlemuller, R., Roy, D. B., Thomas, C. D. (2011): Rapid range shifts of species associated with high levels of climate warming. - Science 333: 1024-26. DOI: $10.1126 /$ science. 1206432.

[12] Claessens, J., Beentjes, K. K., Heijerman, T., Miller, J., Gravendeel, B. (2015): Beobachtungen von Miarus campanulae als Bestäuber von Cephalanthera rubra. - J. Eur. Orchid. 47: 77-87.

[13] Clemente, M. (2009): Orchid Conservation and Trade: Are These Concepts Incompatible? - In: Pridgeon, A. M., Suarez, J. P. (eds.) Proceedings of the Second Scientific Conference on Andean Orchids. Universidad Técnica Particular de Loja, Loja, Ecuador, pp. 46-55.

[14] Cochrane, A., Yates, C. J., Hoyle, G. L., Nicotra, A. B. (2014): Will among-population variation in seed traits improve the chance of species persistence under climate change? Glob. Ecol. Biogeogr. 24: 12-24.

[15] Coumou, D., Rahmstorf, S. (2012): A decade of weather extremes. - Nature Climate Change 2: 491-96.

[16] Cozzolino, S., Widmer, A. (2005): Orchid diversity: an evolutionary consequence of deception? - $\quad$ Trends Ecol Evol 20(9): 487-494. https://doi.org/10.1016/j.tree.2005.06.004.

[17] Dafni, A, Ivri, Y (1981a): The flower biology of Cephalanthera longifoia (Orchidaceae) pollen imitation and facultative floral mimicry. - Plant Syst Evol 137: 229-240.

[18] Dafni, A., Ivri, Y. (1981b): Floral mimicry between Orchis israelitica Baumann and Dafni (Orchidaceae) and Bellevalia flexuosa Boiss. (Liliaceae). - Oecologia 49: 229-232. https://doi.org/10.1007/BF00349193.

[19] Darwin, C. (1984): The Various Contrivances by Which Orchids Are Fertilized by Insects. - University of Chicago Press, Chicago (first published: 1877).

[20] Delfolge, P. (2006): Orchids of Europe, North Africa and the Middle East. - Timber Press, Portland, OR.

[21] Delforge, P. (1995): Orchids of Britain and Europe. - Delachaux et Niestlé Sa, Lausanne.

[22] Engler, R., Randin, C. F., Thuiller, W., Dullinger, S., Zimmermann, N. E., Araújo, M. B., ..., Guisan, A. (2011): 21st century climate change threatens mountain flora unequally across Europe. - Glob. Change Biol. 17: 2330-2341.

[23] Fay, M. F., Taylor, I. (2015): 807. Cephalanthera Rubra. - Curtis's Bot. Mag. 32: 82-90. DOI: $10.1111 /$ curt.12095.

[24] Fitter, A. H., Fitter, R. S. R. (2002): Rapid changes in flowering time in British plants. Science 296: 1689-91.

[25] Forrest, J., Thomson, J. (2011): An examination of synchrony between insect emergence and flowering in Rocky Mountain meadows. - Ecological Monographs 81: 469-491.

[26] Harrap, A., Harrap, S. (2009): Orchids of Britain and Ireland - A Field and Site Guide. A\&C Black Publishers Ltd., London.

[27] Hegland, S. J., Nielsen, A., Lázaro, A., Bjerknes, A. L., Totland, O. (2009): How does climate warming affect plant-pollinator interactions? - Ecology Letters 12.2: 184-195.

[28] Hothorn, T., Bretz, F., Westfall, P. (2008): Simultaneous inference in general parametric models. - Biometrical Journal 50(3): 346-363.

[29] http 1: http://linnaeus.nrm.se/flora/mono/orchida/cepha/cephrubv.jpg.

[30] http 2: https://www.bnpi.hu/hu/reszletek/a-bukk-hegyseg-eghajlata-es-novenyzeti-kepe.

[31] Jackson, G., Webb III, T., Grimm, E. C., Ruddiman, W. F., Wright Jr, H. F. (1987): North America and adjacent oceans during the last deglaciation. - Geological Soc. Amer. 3: $277-88$.

[32] Jakubska-Busse, A., Pielech, R., Szczęśniak, E. (2014): The extinction of terrestrial orchids in Europe: does disappearance of Cephalanthera Rich., 1817 (Orchidaceae, 
Neottieae) species show pattern consistent with the elevation gradient? - Life Sciences Journal 11(4): 140-144.

[33] Janečková, P., Wotavová, K., Schödelbauerová, I., Jersáková, J., Kindlmann, P. (2006): Relative effects of management and environmental conditions on performance and survival of populations of a terrestrial orchid, Dactylorhiza majalis. - Biol. Conserv. 129: 40-49. DOI: 10.1016/j.biocon.2005.09.045.

[34] Jersáková, J., Kindlmann, P., Stnkesky, M. (2002): Population Dynamics of Orchis morio in the Czech Republic under Human Influence. - In: Kindlmann, P., Willems, J. H., Whigham, D. F. (eds.) Trends and Fluctuations and Underlying Mechanisms in Terrestrial Orchid Populations. Backhuys, Leiden, pp. 209-224.

[35] Jersáková, J., Johnson, S. D., Kindlmann, P. (2006): Mechanisms and evolution of deceptive pollination in orchids. - Biol. Rev. 81: 219-235.

[36] Johnston, K. M., Schmitz, O. J. (1997): Wildlife and climate change: assessing the sensitivity of selected species to simulated doubling of atmospheric $\mathrm{CO}_{2}$. - Glob. Change Biol. 3: 531-44.

[37] Kassambara, A. (2017): ggpubr: 'ggplot2' Based Publication Ready Plots. R Package Version 0.1.6.999. - http://www.sthda.com/english/rpkgs/ggpubr.

[38] Kaźmierczakowa, R., Zarzycki, K. (2001): Red Data Book of Poland (in Polish: Polska Czerwona Księga Roślin). - Instytut Botaniki im. Władysława Szafera. Polish Academy of Sciences, Kraków.

[39] Kindlmann, P., Jersáková, J. (2006): Effect of floral display on reproductive success in terrestrial orchids. - Folia Geobot. 41: 47-60. DOI: 10.1007/BF02805261.

[40] Király, G. (2007): Red List of the Vascular Flora of Hungary (in Hungarian: Vörös Lista: A Magyarországi Edényes Flóra Veszélyeztetett Fajai). - Saját Kiadás, Sopron.

[41] Lang, D. (2004): Britain's Orchids. - Wildguides Ltd., Old Basing.

[42] Lenoir, J., Grégout, J. C., Marquet, P. A., de Ruffray, P., Brisse, H. (2008): A significant upward shift in plant species optimum elevation during the 20th century. - Science 320(5884): 1768-1771.

[43] Micheneau, C., Duffy, K. J., Smith, R. J., Stevens, L. J., Stout, J. C., Civeyrel, L., Cowan, R. S., Fay, M. F. (2010): Plastid microsatellites for the study of genetic variability in the widespread Cephalanthera longifolia, C. damasonium and C. rubra (Neottieae, Orchidaceae), and cross-amplification in other Cephalanthera species. - Botanical Journal of the Linnean Society 163: 181-93.

[44] Ministry of National Development and Economy (MNDI) (2010): Integrated Urban Development Strategy. Urban Development Handbook. - MNDI, Jászfényszaru, Hungary.

[45] Molnár, V. A. (2011): Atlas of Orchids in Hungary (in Hungarian). - Kossuth Kiadó, Budapest pp. 375-76 (Kossuth Természettár).

[46] Molnár, V. A. (2015): Climate change and orchids (in Hungarian: Klímaváltozás és orchideák). - Természettudományi Közlöny 146: 1.

[47] Molnár, V. A., Máté, A., Sramkó, G. (2011): An unexpected new record of the Mediterranean orchid, Ophrys bertolonii (Orchidaceae) in Central Europe. - Biologia 66(5): 778-82.

[48] Morellato, L. P. C., Alberton, B., Alvarado, S. T., Borges, B., Buisson, E., Camargo, M. G. G., ... Peres, C. A. (2016): Linking plant phenology to conservation biology. - Biol. Conserv. 195: 60-72.

[49] Newman, R. D., Showler, A. J., Harvey, M. C., Showler, D. A. (2007): Hand pollination to increase seed-set of red helleborine Cephalanthera rubra in the Chiltern Hills, Buckinghamshire, England. - Conservation Evidence 4: 88-93.

[50] Nilsson, L. A. (1983a): Mimesis of bellflower (Campanula) by the red helleborine orchid Cephalanthera rubra. - Nature 305.5937: 799. 
[51] Nilsson, L. A. (1983b): Processes of isolation and introgressive interplay between Platanthera bifolia (L.) Rich and P. chlorantha (Custer) Reichb. (Orchidaceae). Botanical Journal of the Linnean Society 87: 325-350.

[52] Parmesan, C., Hanley, M. E. (2015): Plants and climate change: complexities and surprises. - Annals of Botany 116(6): 849-864. DOI: https://doi.org/10.1093/aob/mcv169.

[53] Parmesan, C., Yohe, G. (2003): A globally coherent fingerprint of climate change impacts across natural systems. - Nature 421(6918): 37-42.

[54] Pellissier, L., Pottier, J., Vittoz, P., Dubuis, A., Guisan, A. (2010a): Spatial pattern of floral morphology: possible insight into the effects of pollinators on plant distributions. Synthesising Ecology 119(11): 1805-1813. https://doi.org/10.1111/j.16000706.2010.18560.x.

[55] Pellissier, L., Vittoz, P., Internicola, A. I., Gigord, L. D. B. (2010b): Generalized fooddeceptive orchid species flower earlier and occur at lower altitudes than rewarding ones. - J. Plant Ecol. 3: 243-250. DOI: 10.1093/jpe/rtq012.

[56] Pillon, Y., Chase, M. (2007): Taxonomic exaggeration and its effects on orchid conservation. - Conserv. Biol. 21(1): 263-265.

[57] Pridgeon, A. (1996): Orchids: Status Survey and Conservation. Action Plan. - IUCN, Gland.

[58] R Core Team (2017): R: A Language and Environment for Statistical Computing. - R Foundation for Statistical Computing, Vienna, Austria. https://www.R-project.org/.

[59] Rahmstorf, S., Coumou, D. (2011): Increase of extreme events in a warming world. Proc. Natl. Acad. Sci. USA 108: 17905-09.

[60] Rankou, H. (2011): Cephalanthera rubra. The IUCN Red List of Threatened Species 2011. - IUCN, Gland.

[61] Renner, S. S. (2006): Rewardless Flowers in the Angiosperms and the Role of Insect Cognition in Their Evolution. - In: Waser, N. M., Ollerton, J. (eds.) Plant-Pollinator Interactions: from Specialization to Generalization. The University of Chicago Press, Chicago, IL, pp. 123-44.

[62] Root, T. L., Price, J. L., Hall, K. R., Schneider, S. H., Rosenzweig, C., Pounds, J. A. (2003): Fingerprints of global warming on wild animals and plants. - Nature 421: 57-60.

[63] Rumpf, S. B., Hülber, K., Klonner, G., Moser, D., Schütz, M., Wessely, J., Willner, W., Zimmermann, N. E., Dullinger, S. (2018): Range dynamics of mountain plants decrease with elevation. - Proc. Natl. Acad. Sci. 115: 1848-1853. DOI: 10.1073/pnas.1713936115.

[64] Scacchi, R., De Angelis, G., Corbo, R. M. (1991): Effect of the breeding system on the genetic structure in three Cephalanthera spp. (Orchidaceae). - Plant Syst. Evol. 176: 5361. DOI: 10.1007/BF00937945.

[65] Scotland, R. W., Wortley, A. H. (2003): How many species of seed plants are there? Taxon 52: 101-04.

[66] Seaton, P. T., Hu, H., Perner, H., Pritchard, H. W. (2010): Ex situ conservation of orchids in a warming world. - The Botanical Review 76: 193-203.

[67] Selby, M. J. (1976): Slope erosion due to extreme rainfall: a case study from New Zealand. - Geografiska Annaler. Series A, Physical Geography 58: 131-38.

[68] Sonkoly, J. Vojtkó, A. E., Tökölyi, J., Török, P., Sramkó, G., Illyés, Z., Molnár, V. A. (2016): Higher seed number compensates for lower fruit set in deceptive orchids. Journal of Ecology 104(2): 343-351. https://doi.org./10.1111/1365-2745.12511.

[69] Suetsugu, K., Naito, R. S., Fukushima, S., Kawakita, A., Kato, M. (2015): Pollination system and the effect of inflorescence size on fruit set in the deceptive orchid Cephalanthera falcata. - J. Plant Res. 128: 585-594. DOI: 10.1007/s10265-015-0716-9.

[70] Summerhayes, V. S. (1985): Wild Orchids of Britain. - Collins, London.

[71] Szlachetko, D., Skakuj. M. (1996): Orchids of Poland (in Polish: Storczyki Polski). Sorus, Poznań. 
[72] Tałałaj, I., Ostrowiecka, B., Włostowska, E., Rutkowska, A., Brzosko, E. (2017): The ability of spontaneous autogamy in four orchid species: Cephalanthera rubra, Neottia ovata, Gymnadenia conopsea, and Platanthera bifolia. - Acta Biol. Cracoviensia s. Bot. 59: 51-61. DOI: 10.1515/abcsb-2017-0006.

[73] Thomas, C. D., Cameron, A., Green, R. E., Bakkene, M. B., Beaumont, L. J., Collingham, Y. C., Erasmus, B. F., De Siqueira, M. F., Gringer, A., Hannah, L., Huges, L., Huntley, B., Van Jarrsveld, A. S., Midgley, G. F., Miles, L., Ortega-Hueta, M. L., Petersen, A. T., Phillips, O. L., Williams, S. E. (2004): Extinction risk from climate change. - Nature 427: 145-48.

[74] Thompson, R. S. (1990): Late Quaternary Vegetation and Climate in the Great Basin. In: Betancourt, J. L., Van Devender, T. R., Martin, P. S. (eds.) Packrat Middens: The Last 40000 Years of Biotic Change. The University of Arizona Press, Tucson, Arizona, pp. 200-239.

[75] Thuiller, W., Lavorel, S., Araújo, M. B., Sykes, M. T., Prentice, I. C. (2005): Climate change threats to plant diversity in Europe. - Proceedings of the National Academy of Sciences 102: 8245-50.

[76] Tremblay, R. L., Ackerman, J. D., Zimmerman, J. K., Calvo, R. N. (2005): Variation in sexual reproduction in orchids and its evolutionary consequences: a spasmodic journey to diversification. - Biological Journal of the Linnean Society 84: 1-54. DOI: 10.1111/j.1095-8312.2004.00400.x.

[77] Tutin, T. G., Heywood, V. H., Burges, N. A., Moore, D. M., Valentine, D. H., Walters, S. M., Webb, D. A. (1980): Flora Europaea. 5. - Cambridge University Press, Cambridge.

[78] Tuulik, T. (1998): Orchids of Hiiumaa (in Estonian: Hiiumaa orhideed). - Pirrujaak 5 Biosfääri Kaitseala Hiiumaa Keskus, Hiiumaa.

[79] Vakhrameeva, M. G., Tatarenko, I. V., Varlygina, G. K., Zagulskii, M. N. (2008): Orchids of Russia and Adjacent Countries (Within the Borders of the Former USSR). A. R. G. Gantner Verlag, Ruggell, Liechtenstein.

[80] Venables, W. N., Ripley, B. D. (2002): Modern Applied Statistics with S. Fourth Ed. Springer, New York.

[81] WMO, World Meteorological Organization (2011): Weather Extremes in a Changing Climate: Hindsight on Foresight. - WMO, Geneva.

[82] Woodward, F. I., Lomas, M. R., Betts. R. A. (1998): Vegetation-climate feedback in a greenhouse world. - Phil. Trans. R. Soc. Lond. B 353: 29-39.

[83] Young, A. G., Hill, J. H., Murray, B. G., Peakall, R. (2002): Breeding system, genetic diversity and clonal structure in the sub-alpine forb Rutidosis leiolepis F. Muell. (Asteraceae). - Biol. Conserv. 106: 71-78. DOI: 10.1016/S0006-3207(01)00230-0.

[84] Ziegenspeck, H. (1936): Orchidaceae. - In: Inkirchner, O., Loew, E., Schroeter, C. (eds.) Lebensgeschichte der Blütenpflanzen Mitteleuropas. Band. 1, Abt. 4. Enke, Stuttgart. 


\section{APPENDIX}

Table A1. The results of the pair-wise comparisons according to the degree of the deviation in the height of the individuals. The significant differences between the habitats are bold and marked with stars

\begin{tabular}{c|c|c|c|c}
\hline \multirow{2}{*}{ Population pair } & \multirow{2}{*}{ Estimate } & \multicolumn{2}{|c|}{ 95\% confidence interval } & \multirow{2}{*}{ Adjusted p-value } \\
\cline { 3 - 4 } & & Lower & Upper & \\
\hline J - BB & $\mathbf{2 . 1 2 5}$ & $\mathbf{1 . 8 3}$ & $\mathbf{2 . 4 6 7}$ & $<\mathbf{1 e - 0 4} * * *$ \\
J - KO & $\mathbf{1 . 7 9}$ & $\mathbf{1 . 4 1 8}$ & $\mathbf{2 . 2 8}$ & $<\mathbf{1 e - 0 4} * * *$ \\
J - PP & $\mathbf{1 . 8 6}$ & $\mathbf{1 . 4 9 7}$ & $\mathbf{2 . 3 2}$ & $<\mathbf{1 e - 0 4} * * *$ \\
KO - BB & 1.181 & 1.09 & 5.86 & 0.281 \\
PP - BB & 1.14 & 0.912 & 1.425 & 0.424 \\
PP - KO & 0.965 & 0.722 & 1.29 & 0.989 \\
\hline
\end{tabular}

Table A2. The results of the pair-wise comparisons according to the degree of the deviation in the number of leaves. The significant differences between the habitats are marked with three stars

\begin{tabular}{c|c|c|c|c}
\hline \multirow{2}{*}{ Population pair } & \multirow{2}{*}{ Estimate } & \multicolumn{2}{|c|}{ 95\% confidence interval } & \multirow{2}{*}{ adjusted p-value } \\
\cline { 3 - 4 } & & Lower & Upper & \\
\hline J - BB & $\mathbf{1 . 3 0 0}$ & $\mathbf{1 . 2 0 0}$ & $\mathbf{1 . 4 1 7}$ & $<\mathbf{0 . 0 0 1 * * *}$ \\
J - KO & $\mathbf{1 . 1 4 0}$ & $\mathbf{1 . 0 0 5}$ & $\mathbf{1 . 3 0 0}$ & $\mathbf{0 . 0 3 9 0 *}$ \\
J - PP & 1.012 & 1.106 & 1.134 & 0.9920 \\
KO - BB & 1.140 & 1.000 & 1.306 & 0.0579 \\
PP - BB & $\mathbf{1 . 2 8 8}$ & $\mathbf{1 . 1 4 3}$ & $\mathbf{1 . 4 5 2}$ & $<\mathbf{0 . 0 0 1 * * *}$ \\
PP - KO & 1.129 & 0.966 & 1.320 & 0.1820 \\
\hline
\end{tabular}

Table A3. The results of the pair-wise comparisons according to the degree of the deviation in the leaf area. The significant differences between the habitats are bold and marked with stars

\begin{tabular}{c|c|c|c|c}
\hline \multirow{2}{*}{ Population pair } & \multirow{2}{*}{ Estimate } & \multicolumn{2}{|c|}{$\mathbf{9 5 \%}$ confidence interval } & \multirow{2}{*}{ Adjusted p-value } \\
\cline { 2 - 4 } & & Lower & Upper & \\
\hline BB - J & $\mathbf{- 0 . 4 2 9}$ & $\mathbf{- 0 . 6 2 7}$ & $\mathbf{- 0 . 2 3 2}$ & $<\mathbf{1 e - 0 4} * * *$ \\
KO - J & $\mathbf{- 0 . 5 1 8}$ & $\mathbf{- 0 . 8 3 2}$ & $\mathbf{- 0 . 2 0 4}$ & $<\mathbf{0 . 0 0 1} * * *$ \\
PP - J & $\mathbf{- 0 . 5 8 0}$ & $\mathbf{- 0 . 8 6 9}$ & $\mathbf{- 0 . 2 9 0}$ & $<\mathbf{1 e - 0 4} * * *$ \\
BB - KO & 0.089 & -0.231 & 0.409 & 0.8875 \\
PP - BB & -0.150 & -0.445 & 0.145 & 0.5493 \\
PP- KO & -0.061 & -0.444 & 0.322 & 0.9755 \\
\hline
\end{tabular}


Table A4. The results of the pair-wise comparisons according to the degree of the deviation in the number of flowers/individuals. The significant differences between the habitats are bold and marked with stars

\begin{tabular}{c|c|c|c|c}
\hline \multirow{2}{*}{ Population pair } & \multirow{2}{*}{ Estimate } & \multicolumn{2}{|c|}{ 95\% confidence interval } & \multirow{2}{*}{ Adjusted p-value } \\
\cline { 3 - 4 } & & Lower & Upper & \\
\hline J - BB & $\mathbf{1 . 8 3 9}$ & $\mathbf{1 . 3 8 5}$ & $\mathbf{2 . 4 4 1}$ & $<\mathbf{0 . 0 0 1} * * *$ \\
J - KO & 1.280 & 0.828 & 1.980 & 0.460 \\
J - PP & 0.913 & 0.625 & 1.335 & 0.925 \\
KO - BB & 1.437 & 0.912 & 2.265 & 0.169 \\
PP - BB & $\mathbf{2 . 0 1 4}$ & $\mathbf{1 . 3 4 8}$ & $\mathbf{3 . 0 1 0}$ & $<\mathbf{0 . 0 0 1}$ *** \\
PP - KO & 1.400 & 0.833 & 2.358 & 0.337 \\
\hline
\end{tabular}

Table A5. The results of the pair-wise comparisons according to the degree of the deviation in the number of fruits/individuals. The significant differences between the habitats are marked with three stars

\begin{tabular}{c|c|c|c|c}
\hline \multirow{2}{*}{ Population pair } & \multirow{2}{*}{ Estimate } & \multicolumn{2}{|c|}{ 95\% confidence interval } & \multirow{2}{*}{ Adjusted p-value } \\
\cline { 2 - 4 } & & Lower & Upper & \\
\hline BB - J & $\mathbf{1 6 . 6 6}$ & $\mathbf{7 . 2 4 0}$ & $\mathbf{3 8 . 4 6}$ & $<\mathbf{0 . 0 0 1} * * * *$ \\
KO - J & $\mathbf{2 7 . 2 7}$ & $\mathbf{1 0 . 5 8}$ & $\mathbf{7 0 . 2 4}$ & $<\mathbf{0 . 0 0 1} * * *$ \\
PP - J & $\mathbf{4 . 6 3}$ & $\mathbf{1 . 5 5 0}$ & $\mathbf{1 3 . 8 3}$ & $\mathbf{0 . 0 0 1 9 * *}$ \\
KO - BB & 1.646 & 0.874 & 3.10 & 0.1767 \\
BB - PP & $\mathbf{3 . 5 8}$ & $\mathbf{1 . 5 4 7}$ & $\mathbf{8 . 2 8}$ & $<0.001 * * *$ \\
KO - PP & $\mathbf{5 . 8 9}$ & $\mathbf{2 . 2 6 0}$ & $\mathbf{1 5 . 3 3}$ & $<\mathbf{0 . 0 0 1} * * *$ \\
\hline
\end{tabular}

Figure A1. The distribution of the different traits in the different populations
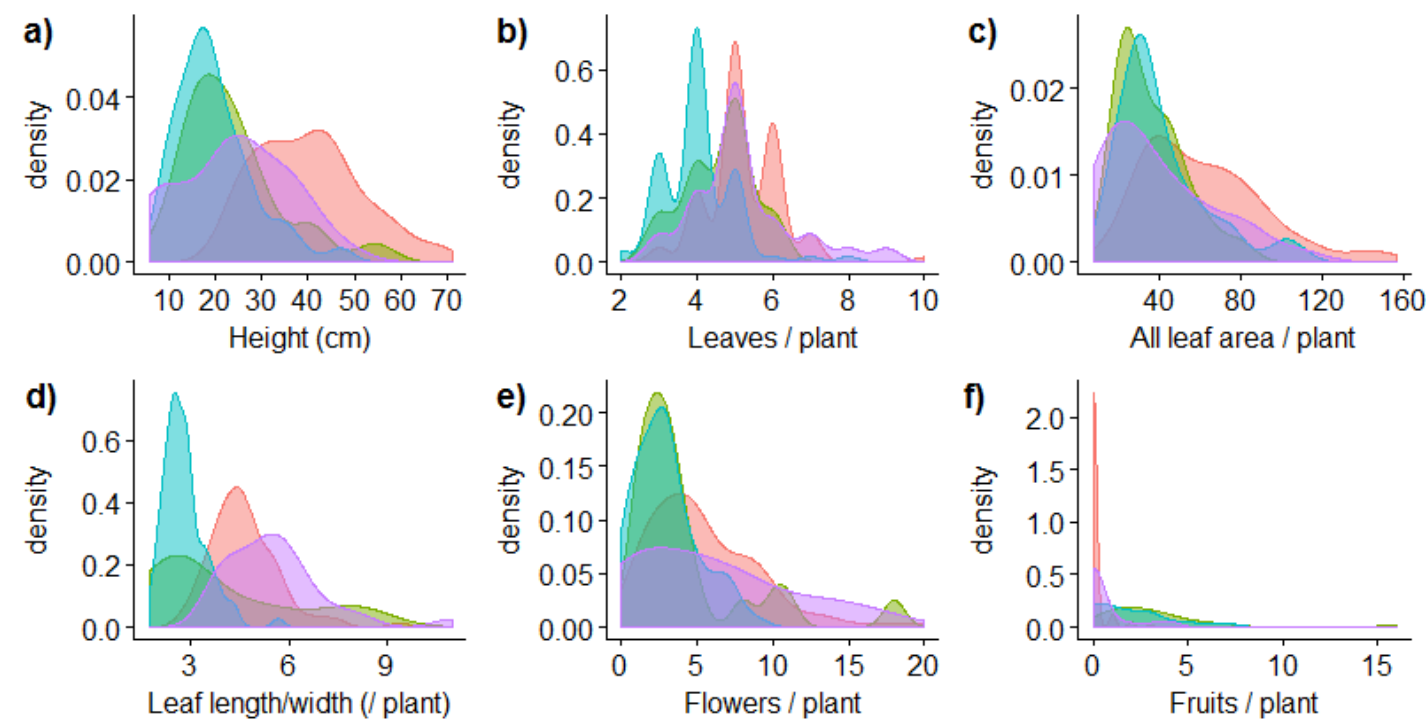

Population (altitude) $\square \mathrm{J}(103 \mathrm{~m}) \square \mathrm{KO}(361 \mathrm{~m}) \square$ BB (533m) $\square$ PP (657m) 
Figure A2. Number of fruits/individual in the different populations. In the KO population there was one plant which had an extremely high number of fruits, which makes difficult to see the slight differences between the populations
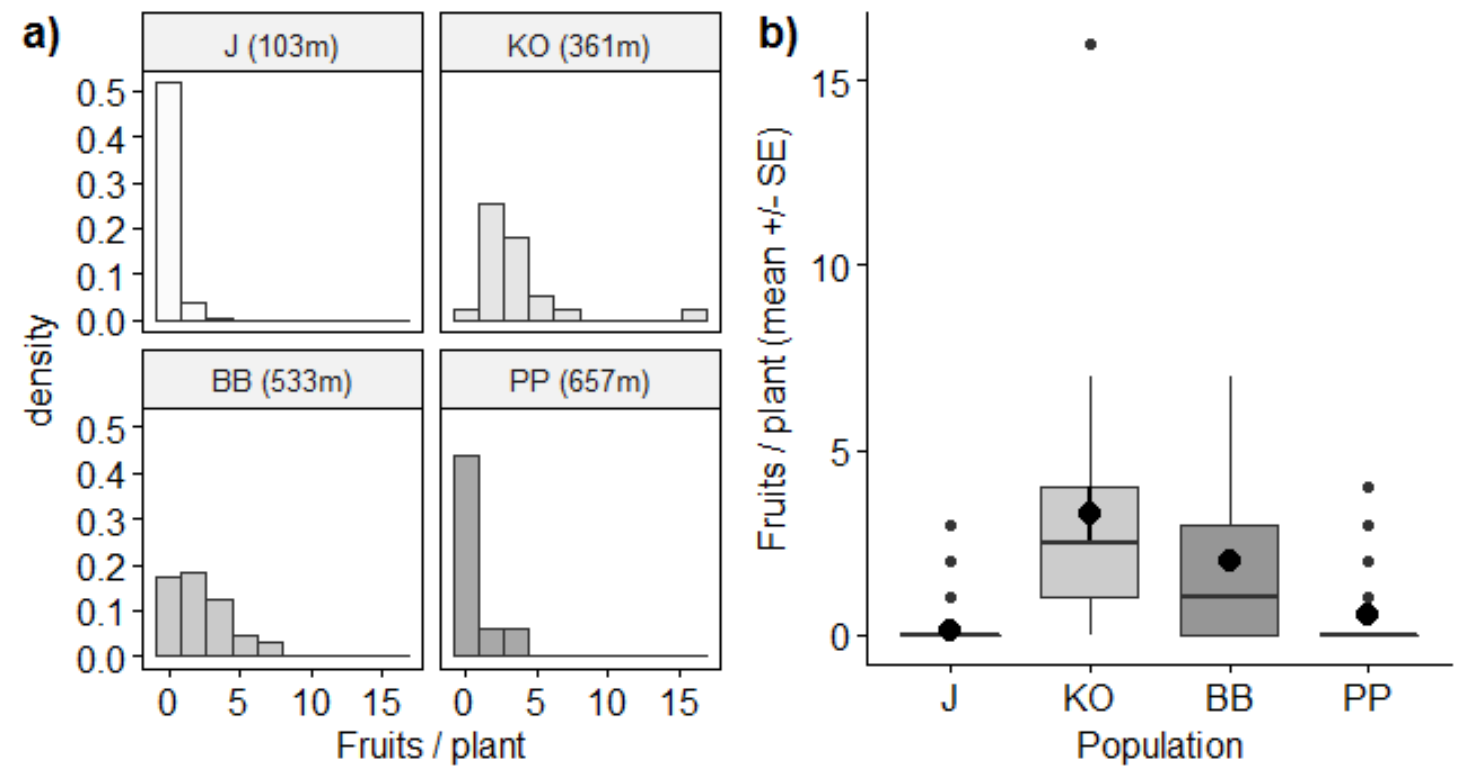